\title{
The Feasibility of Red Chili in Independent and Group Sales Systems in Sukamantri Subdistrict, Ciamis Regency
}

\author{
Nuri Nabila Nurohmah ${ }^{1 *}$, Triwara Buddhi $\mathrm{S}^{1}$, Eni Istiyanti ${ }^{1}$ \\ ${ }^{1}$ Department of Agribusiness, Faculty of Agriculture, Universitas Muhammadiyah Yogyakarta \\ *Corresponding author. Email: nuri.nabila.2016@fp.umy.ac.id
}

\begin{abstract}
Chili peppers are one of the horticultural commodities commonly cultivated commercially in tropical regions such as Indonesia. Sukamantri sub-district is the center of chili plants in Ciamis Regency with the largest planting area and harvest area of 296 hectares and the largest production value in Ciamis Regency of 37,644 tons. There are two red chili sales systems in Sukamantri sub-district, namely independent sales system and group sales system. This research aims to analyze the cost, revenue, profit and feasibility of red chili farming on independent and group sales systems. Location determination is done deliberately in Sukamantri District, Ciamis Regency. Respondents used two methods, namely snow ball sampling on independent farmers and simple random sampling on group farmers. The total sample taken was 64 respondents consisting of 30 independent farmers and 34 group farmers. The results showed that the average cost spent by red chili farmers 0.25 hectares in one season was IDR $16,343,800$ of the independent farmers and IDR 18,592,545 of the group farmers with income IDR $27,983,625$ of independent farmers and IDR 32,507,004 of the group farmers. Each profit obtained by independent farmers is IDR 24,015,175 and the group is IDR 28,972,885. The feasibility of red chilli farming in the independent and group sales system in Sukamantri District is seen from the R / C, land productivity, labor productivity and capital productivity are feasible to be developed. The R / C value obtained for independent farmer was 2.47 and for group farmer was 2.5 , while the productivity value of each farmer was IDR 94,877,540/ha and IDR $113,998,539 /$ ha. The labor productivity of the independent farmer is IDR 277,779 / HKO and for group farmer is IDR.443.882/HKO and capital productivity value is $194.1 \%$ in independent farmers and $192.40 \%$ in group farmers.
\end{abstract}

Keywords—red chili, feasibility, sales system

\section{INTRODUCTION}

One of the horticultural commodities that is commonly cultivated by farmers is chili. In Indonesia, chilies are grown every season because chili is one of the commodities that is consumed every day. Chili is also an important type of vegetable that is cultivated commercially in tropical areas such as Indonesia. [9]

The high demand for chilies for the needs of cooking spices, the food industry and medicine is a potential for reaping profits. It is not surprising that chili is one of the horticultural commodities that as the highest price fluctuation in Indonesia.

Based on Figure 1, the need for red chili consumption in Indonesia tends to increase in 2016 to 2019. If we look at the 2016 consumption (kg/ capita/ year) for chili, the total consumption of chili is $2.90 \mathrm{~kg} /$ capita, in $2017(2.95 \mathrm{~kg} /$ capita), 2018 (3.00 kg / capita) and 2019 (3.05 kg/ capita). For red chilies in 2016 the amount of consumption was 1.55 (kg/ capita), in the 20 Domestic Trade Assessment Centers in 2017 the total consumption was 1.56 (kg/ capita) and in 2019 it was 1.58 (kg/ capita). ). While for cayenne pepper consumption in 2016 is 1.35 ( $\mathrm{kg} /$ capita), in 2018 consumption is 1.43 ( $\mathrm{kg} /$ capita), in 2019 it is predicted to be 1.46 ( $\mathrm{kg} /$ capita).

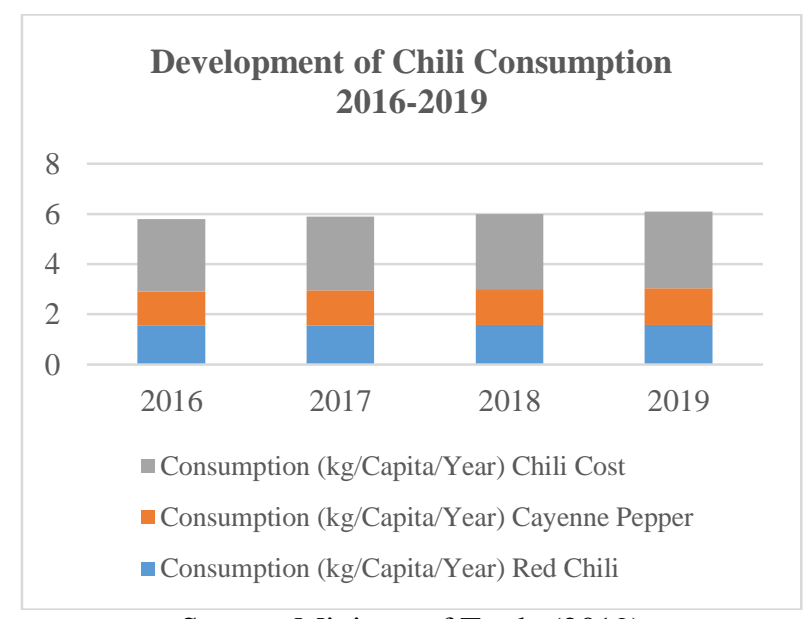

Source: Ministry of Trade (2019)

Figure 1. Consumption Development 2016-2019

West Java is one of the centers of chili production in Indonesia. Based on the average national large chili 
production in 2010-2014, West Java's contribution reached $22.54 \%$ [14]. If broken down by province on the island of Java, large chili production in 2016 was contributed by three central provinces, namely West Java $(45.21 \%)$, Central Java (30.81\%) and East Java (17.84\%) [5]. One district that does red chili farming is Ciamis district.

Ciamis Regency is one of the regencies located in West Java with an economic characteristic that is dominated by the agricultural sector which includes food crop agriculture, horticulture, animal husbandry, plantation, forestry and fisheries. Lowland rice production is the main commodity in the agricultural sector in Ciamis Regency. In 2018, the harvested area for paddy rice was recorded at 81,734 hectares, in contrast to the condition for field rice, which decreased from 101 hectares in 2017 to 85 hectares in 2018. Vegetable production generally decreased in 2017 including chili and Chinese cabbage. However, the decline in vegetable production, especially chili peppers in Ciamis Regency, still has the largest production value in Ciamis Regency.

Based on Central Statistics Agency in 2019, it is stated that the largest harvested area and vegetable crop production in Ciamis Regency between 2017-2018 is chili plants with a harvest area of 755 hectares and a production yield of 83,735 $\mathrm{Kw}$. Red chili farming in Ciamis Regency has been cultivated in 27 sub-districts in Ciamis Regency with a land area of 755 hectares with a production of 83,735 quintals of red chili. One of the sub-districts that are the prima donna of producing red chilies in Ciamis Regency is Sukamantri District. Sukamantri District is the center of chili plants in Ciamis Regency with the largest planting area and harvest area of 296 hectares and the largest production value in Ciamis Regency of 37,644 tons. [3]

There are two red chili sales systems in Sukamantri District, namely the independent sales system and the group sales system. An independent sales system means that farmers independently sell their crops to traders, local middlemen and nearby markets. In addition, farmers who sell their crops independently also distribute their crops outside the region. In the group sales system, the sale of crops is managed by the group and held by a coordinator who is responsible for finding markets outside the area for farmers. Some areas that are selling red chili peppers in Sukamantri District include Jakarta and Cirebon. With the existence of a different sales system, it will certainly affect the price of red chilies and income and even profit for each farmer.

Based on the description above, it is necessary to study how much costs are incurred as well as the income and profits obtained by farmers, both with the independent and group sales system. In addition, it is necessary to study the feasibility of the red chili farming obtained by the independent and group sales system.

The purpose of this study was to determine the costs, income, benefits and feasibility of farming red chili in independent and group sales systems in Sukamantri District, Ciamis Regency.

\section{RESEARCH METHODS}

The research method used in this research is descriptive research methods and quantitative research methods. The descriptive research method is research that is intended to describe the state of the research object [11] while the quantitative method is one of the ways used to answer research problems related to data in the form of numbers and statistical programs [12]. The research location was conducted in Sukamantri District, Ciamis Regency, West Java. The location was chosen purposively (intentionally) because Sukamantri District is one of the largest red chilli pepper producers and centers in Ciamis Regency. Respondents taken in this study were 64 people, including 30 independent farmers and 34 group farmers. Sampling was done in two ways, namely snowball sampling technique for independent farmers and simple random sampling technique for group farmers. The sampling of group farmers was taken from the largest number of farmer groups in Sukamantri District.

To find out the cost of farming, the following formula is used:

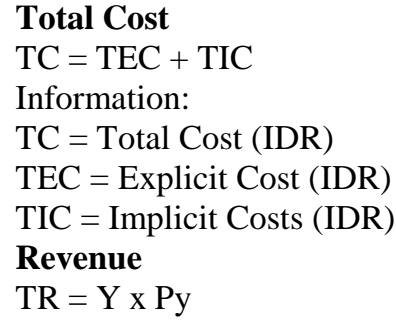

Profit TEC $=$ Total Explicit Costs [10]

$$
\begin{gathered}
\Pi=\text { TR }-(\text { TEC }+ \text { TIC }) \\
\text { Information: } \\
\Pi=\text { Profits } \\
\text { TR = Total Revenue } \\
\text { TC = Total Cost } \\
\text { TEC = Total Explicit Costs } \\
\text { TIC = Total Implicit Costs }
\end{gathered}
$$

To find out the feasibility of red chili farming, it can be seen from several factors as follows:

$$
\begin{aligned}
& \text { R / C Ratio } \\
& \mathrm{R} / \mathrm{C}=\frac{T R}{T C}
\end{aligned}
$$

Information:

$$
\begin{gathered}
\text { TR }=\text { Total Revenue } \\
\text { TC }=\text { Total cost }
\end{gathered}
$$




\section{Land Productivity}

Produktivitas Lahan $\frac{P d-T K D K-\text { Cost Of Equity }}{\text { Land Are }}$

(6)

Information:

$\mathrm{Pd}=$ Income

TKDK $=$ Workers in the Family

Labor Productivity

Produktivitas Tenaga Kerja $\frac{P d-S L S-C o s t ~ O f ~ E q u i t y}{T K D K(H K O)}$ Information: $\mathrm{Pd}=$ Income

SLS $=$ Own Lease of Land

TKDK = Domestic Workers (HKO) $\mathrm{HKO}=$ People Working Days

Capital Productivity

$$
\begin{aligned}
\text { Capital Productivity } & =\frac{\boldsymbol{P d}-\boldsymbol{S} \boldsymbol{L} \boldsymbol{S}-\boldsymbol{T K} \boldsymbol{D} \boldsymbol{K}}{\boldsymbol{T E C}} \\
& \text { Information: } \\
& \text { Pd }=\text { Income } \\
\text { SLS } & =\text { Own Lease of Land } \\
\text { TKDK } & =\text { Workers in the Family } \\
\text { TEC } & =\text { Total Explicit Costs }
\end{aligned}
$$

\section{RESULTS AND DISCUSSION}

\subsection{Group Farmer}

A farmer group is a group or joint institution owned by farmers that develops by and for farmers. Sukamantri subdistrict consists of five villages including Cibeureum, Sindanglaya, Mekarwangi, Tenggerraharja, and Sukamantri villages. In addition, in each of these villages several red chili farmer groups are formed. The main activity of farmer groups in Sukamantri District is more on mentoring and collective deliberations related to ongoing agricultural problems. Each farmer group will be coordinated by a chairman and each chairman has a different number of group members.

Farmers who are members of farmer groups will usually sell their crops through Gapoktan which are available in every village. The sales system is said to be selling in groups, but it does not rule out the possibility of Gapoktan receiving crops from independent farmers. Farmers who market their crops through Gapoktan will submit the total price and also

\begin{tabular}{|c|c|c|}
\hline No. & Village & Group \\
\hline 1 & \multirow{5}{*}{ Cibeureum } & Mount Sari \\
\hline 2 & & Gunung Sari II \\
\hline 3 & & Gunung Sari V \\
\hline 4 & & Gunung Sari IV \\
\hline 5 & & Karang Sari \\
\hline
\end{tabular}
the market to Gapoktan parties. In this case, farmers will give

\begin{tabular}{|c|c|c|}
\hline No. & Village & Group \\
\hline 6 & & Kencana Sari \\
\hline 7 & & Kencana Sari II \\
\hline 8 & & Kencana Sari III \\
\hline 9 & & Kencana Sari IV \\
\hline 10 & & Mekar Jaya \\
\hline 11 & & Love Bloom \\
\hline 12 & & Love Mekar II \\
\hline 13 & & Cinta Mekar IV \\
\hline 14 & & Guna Sari IV \\
\hline 15 & & Buana Mekar II \\
\hline 16 & & Buana Bloom \\
\hline 17 & & Mekar Sari \\
\hline 18 & \multirow{11}{*}{ Sindanglaya } & Sindang Mulya \\
\hline 19 & & Mulyasari \\
\hline 20 & & Harapan Mulya I \\
\hline 21 & & Mulya twins \\
\hline 22 & & Sindang Mulya 3 \\
\hline 23 & & Buds of Hope \\
\hline 24 & & Galuh Rahayu \\
\hline 25 & & Sugih Mukti 2 \\
\hline 26 & & Sugih Mukti \\
\hline 27 & & Kaya Mukti II \\
\hline 28 & & Galuh Rahayu 3 \\
\hline
\end{tabular}
$10 \%$ of their income to Gapoktan. The following is a list of farmer groups formed in Cibeureum and Sindanglaya Villages, Sukamantri District:

Table 1. List of Farmer Groups in Sukamantri District
Source: BP3K document Sukamantri District

\subsection{Independent Farmers}

Independent farmers are farmers who are not part of a farmer group in Sukamantri District. In general, independent farmers are farmers who do red chili farming personally, both in terms of providing production facilities and other financing. In its implementation, independent farmers do not have the right to receive assistance from the government in the form of production or financial means. Independent farmers generally sell their crops directly to local middlemen and to nearby markets. Some independent farmers sell their crops through Gapoktan which are available in each village as well as group farmers. Overall, between independent and group farmers the sales system is not too different.

\subsection{Identity of Farmers}

Farmers are farming actors who carry out a series of input production activities and produce an output. This research describes the components of the farmer's identity which include age, gender, education level, farming experience, average land area and land ownership status. 
Table 2. Identity of Independent Farmers and Groups

\begin{tabular}{|c|c|c|c|c|}
\hline \multirow{2}{*}{ Description } & \multicolumn{2}{|c|}{ Independent } & \multicolumn{2}{|c|}{ Group } \\
\hline & Amount & Percentage (\%) & Amount & Percentage (\%) \\
\hline Farmer Age (Years) & \multirow{2}{*}{ then } & \multirow[b]{2}{*}{0} & \multirow[b]{2}{*}{9} & \multirow[b]{2}{*}{26} \\
\hline $30-40$ & & & & \\
\hline $41-51$ & \multirow{2}{*}{$\begin{array}{c}26 \\
4\end{array}$} & \multirow{2}{*}{$\begin{array}{l}87 \\
13\end{array}$} & \multirow{2}{*}{$\begin{array}{c}17 \\
8\end{array}$} & \multirow{2}{*}{$\begin{array}{l}50 \\
24\end{array}$} \\
\hline$>51$ & & & & \\
\hline Gender (Soul) & \multirow{3}{*}{$\begin{array}{c}28 \\
2\end{array}$} & \multirow{3}{*}{$\begin{array}{c}93 \\
7\end{array}$} & \multirow{3}{*}{$\begin{array}{c}32 \\
2\end{array}$} & \multirow{3}{*}{$\begin{array}{c}94 \\
6\end{array}$} \\
\hline Male & & & & \\
\hline Women & & & & \\
\hline Education & \multirow[b]{2}{*}{0} & \multirow[b]{2}{*}{0} & \multirow[b]{2}{*}{1} & \multirow[b]{2}{*}{3} \\
\hline No school & & & & \\
\hline Elementary School & \multirow{2}{*}{$\begin{array}{c}18 \\
7\end{array}$} & 60 & \multirow{2}{*}{$\begin{array}{c}24 \\
0\end{array}$} & 70 \\
\hline Junior High & & 23 & & 0 \\
\hline High school & 5 & 17 & 9 & 27 \\
\hline College & 0 & 0 & 0 & 0 \\
\hline Farming Experience (Years) & \multirow{3}{*}{25} & \multirow[b]{2}{*}{83} & \multirow[b]{2}{*}{25} & \multirow[b]{2}{*}{74} \\
\hline $3-10$ & & & & \\
\hline $11-20$ & & 17 & 9 & 26 \\
\hline$>20$ & 0 & 0 & 0 & 0 \\
\hline Land Use Area (Ha) & \multirow{3}{*}{$\begin{array}{c}30 \\
0\end{array}$} & \multirow[b]{2}{*}{100} & \multirow[b]{2}{*}{16} & \\
\hline$<0.25$ & & & & 47 \\
\hline $0.25-1$ & & 0 & 16 & 47 \\
\hline$<1$ & 0 & 0 & 2 & 6 \\
\hline Land Ownership Status & & & & \\
\hline Private property & 11 & 37 & 2 & 6 \\
\hline Rent & 19 & 63 & 32 & 94 \\
\hline
\end{tabular}

Based on the table above, it shows that the majority of red chili farmers with an independent and group sales system in Sukamantri District are at the age of 41-51. The red chili farmers who use the independent sales system are in the age range 41-51 with a percentage of $87 \%$ of 26 farmers, while the red chili farmers with the group sales system show a percentage of $50 \%$ of 17 farmers. In the age range of 30-40 years, the majority of farmers who cultivate red chilies are farmers who use a group selling system or are members of farmer groups. The category of farmers in the 30-40 year age group is indicated by a percentage of $26 \%$ with 9 farmers. In the age range $>51$ years, the majority of red chili farmers are also shown by group farmers with a percentage of $24 \%$ of the total 8 farmers,

In the gender component, the majority of red chili farmers in Sukamantri District are male, both independent farmers and group farmers. The number of male farmers in independent farmers is indicated by a percentage of $93 \%$ with a total of 28 people and a percentage of $7 \%$ with a total of 2 female farmers, while the number of male farmers in group farmers is 32 people with a percentage of $94 \%$ and 2 female farmers with a percentage of $6 \%$.

The education level of red chili farmers in Sukamantri District, both independent farmers and farmers in the majority group, is elementary school graduates, namely $60 \%$ with 18 independent farmers and $70 \%$ with 24 group farmers. As for group farmers who do not have a history of education with a percentage of $3 \%$ of the total 1 person, junior high school graduates are indicated by independent farmers with a percentage of $23 \%$ of the total 7 farmers. $17 \%$ of Senior High School graduates are independent farmers, and $27 \%$ of them are 9 group farmers.

Farming experience is an important aspect of farming activities. This is because the farming experience is a time or farming activity that has been carried out continuously. As for the majority of red chilli farmers in Sukamantri Subdistrict have experience of farming red chilies, including 3-10 years and indicated by a percentage of $83 \%$ with 25 independent farmers and $74 \%$ with 25 group farmers. The minimum length of farming experience is 11-20 years, based on the table above states that there are 5 independent farmers with a percentage of $17 \%$ and 9 group farmers with a percentage of $26 \%$

Land is one of the factors of production that is very influential in farm production. The larger the land that is owned, the red chili production that will be produced will be large.Based on the table above, it can be seen that the area of land used to do red chili farming in Sukamantri District with the highest percentage is $<0.25$ ha or $100 \%$ for independent farmers and $47 \%$ for group farmers. Then the land area between $0.25-1$ ha is $47 \%$ for group farmers only and land area of more than 1 ha is $6 \%$ with 2 group farmers. In its implementation, the average area of red chili pepper in group farmers is greater than that of independent farmers. The 
average area for own and leased land is 0.25 hectares for both independent and group interests.

In addition, in the component of land ownership status, it can be seen that the majority of land ownership status in Sukamantri District is leased land, as many as 19 independent farmers with a percentage of $63 \%$ and 32 group farmers with a percentage of $94 \%$. Ownership of private land in red chili farming in Sukamantri District consists of 11 independent farmers and 2 group farmers with a percentage of $37 \%$ and $6 \%$, respectively.

\subsection{Farming Cost Analysis}

\subsubsection{Total Cost}

Table 3. Average cost of red chili farming in Sukamantri District, Ciamis Regency per 0.25 ha

\begin{tabular}{|l|r|r|}
\hline \multirow{2}{*}{ Description } & \multicolumn{1}{c|}{ Independent } & \multicolumn{1}{c|}{ Group } \\
\cline { 2 - 3 } Explicit Cost & Cost (IDR) & \multicolumn{1}{c|}{ Cost (IDR) } \\
TKLK & $3,023,118$ & $5,393,909$ \\
Production Means & $8,075,415$ & $8,214,318$ \\
Depreciation & 992,650 & $1,022,406$ \\
Land lease & 117,500 & 258,676 \\
Miscellaneous & 166,667 & 169,118 \\
expense & & \\
\hline Amount & $\mathbf{1 2 , 3 7 5 , 3 4 9}$ & $\mathbf{1 5 , 0 5 8 , 4 2 7}$ \\
\hline Implicit Cost & & \\
TKDK & $3,907,000$ & $3,523,089$ \\
Rent Own Land & 61,450 & 11,029 \\
Own Capital & 357,240 & 484,280 \\
Interest & & \\
\hline Amount & $\mathbf{3 , 9 6 8 , 4 5 0}$ & $\mathbf{3 , 5 3 4 , 1 1 8}$ \\
\hline Total cost & $\mathbf{1 6 , 3 4 3 , 8 0 0}$ & $\mathbf{1 8 , 5 9 2 , 5 4 5}$ \\
\hline
\end{tabular}

The total cost to be incurred by the red chili farmers per 0.25 hectare is IDR $16,343,800$ for independent farmers and IDR 18,592,545 in group farmers consisting of explicit costs and implicit costs. Red chili farming per 0.25 hectare carried out by farmers in Sukamantri Subdistrict incurs an explicit cost of IDR 12,375,349 for independent farmers and IDR $15,058,427$ for group farmers consisting of costs for labor outside the family, production facilities, depreciation of equipment, costs land rent and other costs. The explicit costs for group farmers tend to be higher than for independent farmers due to the use of labor outside the family and quite large means of production.

Apart from paying explicit costs, farmers also incur implicit costs in their farming. Implicit costs are costs incurred by farmers indirectly but are calculated which include labor costs in the family, rent for own land and interest on their own capital. The majority of farmers in red chili farming in Sukamantri sub-district spend quite a lot on labor costs in the family. The cost of labor in the family is IDR 3,907,000, - to independent farmers and IDR 3,523,089 in group farmers. In the red chili farming in Sukamantri District, the implicit cost incurred is IDR 3,968,450 for independent farmers and IDR 3,543,118 in group farmers.

\subsubsection{Revenue, Income and Profits}

Table 4. Average Revenue, Income and Profits of red chili farming in the independent and group sales system in Sukamantri District, Ciamis Regency.

\begin{tabular}{|c|c|c|}
\hline \multirow{2}{*}{ Description } & \multicolumn{2}{|c|}{ Amount } \\
\hline & Independent & Group \\
\hline Production $(\mathrm{Kg})$ & 3,016 & 3,048 \\
\hline Price (IDR) & 13,200 & 15,485 \\
\hline Revenue (IDR) & $40,358,974$ & $47,565,431$ \\
\hline Explicit Cost (IDR) & $12,375,349$ & $15,058,427$ \\
\hline Implicit Costs (IDR) & $3,968,450$ & $3,534,118$ \\
\hline Income (IDR) & $27,983,625$ & $32,507,004$ \\
\hline Profit (IDR) & $24,015,175$ & $28,972,885$ \\
\hline
\end{tabular}

Based on field data, the production of red chili per 0.25 hectare is $3,016 \mathrm{~kg}$ for independent farmers and 3,048 kg for group farmers per planting season, assuming all production is sold. The chili production obtained by the farmers is then multiplied by the average selling price of IDR 13,200 and IDR 15,485 resulting in an income of IDR 40,358,974, - to independent farmers and IDR 47,565,431, - to group farmers. The difference in the average selling price which is quite large between independent farmers and groups occurs because the price of chili tends to fluctuate, the selling time is not the same and the place where the produce is sold is different. Waldi (2017) in his research on the coastal sand land of Panjatan District, Kulonprogo Regency, stated that the income received by farmers was IDR 40,696. [13]

The average income per 0.25 hectare obtained from chili farming in Sukamantri District is IDR 27,983,625 for independent farmers and IDR 32,507,004 for group farmers, while the profits obtained by farmers amounted to IDR 24,015,175 and IDR 28,972,885.

Pratama, MR (2019) in his research stated that the income of farmers in Lubuk Cuik Village, Lima Puluh District, Batu Bara Regency, North Sumatra is IDR 48,559,526 [6] meanwhile according to Evaliza, et al (2015) in their research entitled Lotanbar Chili Farming Analysis in Support of A New Superior Cultivar from The District of Fifty Cities stated that the income and profits obtained by farmers were IDR 25,256,900 / land area and IDR $24,104,815$ / land area. [4]

\subsection{Feasibility Analysis}

The feasibility of farming red chilies with the independent and group sales system in Sukamantri District can be calculated using four analyzes, namely: R / C, land productivity, labor productivity, and capital productivity. 
Table 5. Feasibility analysis of red chili farming on independent and group sales systems in Sukamantri District, Ciamis Regency.

\begin{tabular}{|c|r|r|}
\hline \multirow{2}{*}{ Description } & \multicolumn{2}{|c|}{ Cost (IDR) } \\
\cline { 2 - 3 } & \multicolumn{1}{|c|}{ Independent } & \multicolumn{1}{c|}{ Group } \\
\hline Total Revenue & $40,358,974$ & $47,565,431$ \\
Total production costs & $16,343,800$ & $18,592,545$ \\
Income (IDR) & $27,983,625$ & $32,507,004$ \\
TKDK (IDR) & $3,907,000$ & $3,523,089$ \\
Own Capital Interest & 357,240 & 484,280 \\
(IDR) & 0.25 & 0.25 \\
Land area (ha) & 61,450 & 11,029 \\
Rent Own Land (IDR) & 99.2 & 72.12 \\
Total TKDK (HKO) & $12,375,349$ & $16,022,410$ \\
Total Explicit Cost \\
(IDR)
\end{tabular}

Based on the table above, red chili farming in the independent and group sales system in Sukamantri District was declared feasible using R/C Ratio analysis. The R/C value obtained is 2.47 for independent farmers and 2.56 for group farmers or greater than 1 . This means that every 1 rupiah spent by farmers will get an income of 2.47 and 2.56 rupiah.

Purba, USA (2019) In his research on inorganic and semi-organic red chili farming in South Lampung Regency, it was stated that the $\mathrm{R} / \mathrm{C}$ obtained was 1.74 for inorganic red chili and 1.53 in semi-organic chilies [7] while according to Zamrodah and Pintakami (2020) in their research, income and the feasibility of cayenne pepper farming states that the $\mathrm{R} / \mathrm{C}$ value obtained is 2.54. [15]

The land productivity value obtained in red chili farming in the independent and group sales system in Sukamantri District, Ciamis Regency is IDR. 94,877,540 / ha and IDR $113,998,539$ / ha. This shows that the value of land productivity is greater than the rental price of 0.25 hectares of land in the study area. This means that the red chili farming in Sukamantri District is feasible to be cultivated. Anggraeni (2018) in his research stated that the productivity of the land in the eruption area of Wukirsari Village, Cangkringan District, Sleman Regency is IDR 12,233 / m2. [1]

The labor productivity obtained is IDR 277,779 / HKO to independent farmers and IDR 443,882 / HKO for group farmers. The labor productivity of independent farmers is smaller than group farmers, this is because the amount of income earned by independent farmers is less than group farmers. The labor wage in Sukamantri District is IDR 30,000 - IDR 50,000 per HKO where 1 HKO equals 6 hours a day. Farming can be said to be feasible if the labor productivity value is greater than the prevailing wage in the research area. Therefore,

In Rudi's research (2016), in the sand land of Karangsewu Village, Galur District, Kulon Progo Regency, it was stated that the labor productivity obtained was IDR. 22,794,060 and the value is declared feasible because it is greater than the prevailing labor wages. [8]

The value of capital productivity obtained in the red chili farming in Sukamantri District is $194.1 \%$ for independent farmers and $192.40 \%$ for group farmers. From the results of the capital productivity obtained, it can be concluded that the red chili farming in Sukamantri District can be said to be feasible because the value of capital productivity obtained is greater than the prevailing loan interest rate in Sukamantri District. The loan interest rate used is BRI bank with an interest rate of $6 \%$ per year so that in one planting season the prevailing interest rate is $3 \%$ per planting season.

Anggraeni (2018) in his research in the eruption area of Merapi, Wukirsari Village, Cangkringan District, Sleman Regency, stated that the capital productivity obtained was $8.22 \%$ which means that it is feasible to do red chili farming. [1]

\section{CONCLUSIONS AND SUGGESTIONS}

\subsection{Conclusion}

The results of research conducted in Sukamantri District regarding the Feasibility of Red Chili Farming in the Independent and Group Sales System can be concluded as follows:

1. The average cost of red chili farming in Sukamantri District is IDR. 16,343,800 for independent farmers and IDR. 18,592,545 for group farmers per 0.25 hectare per one planting season, while the income earned per 0.25 hectare per one planting season is IDR. 27,983,625 for independent farmers and IDR. 32,507,004 for group farmers. Each of the profit obtained by independent farmers and group farmers in Sukamantri District is IDR 24,015,175 and IDR 28,972,885.

2. Red chili farming in the independent and group sales system in Sukamantri District, Ciamis Regency, was declared feasible to be cultivated as seen from $\mathrm{R} / \mathrm{C}$, land productivity, labor productivity, and capital productivity. The results of the $\mathrm{R} / \mathrm{C}$ analysis obtained were 2.47 for independent farmers and 2.56 for group farmers, while the value of land productivity of each farmer was IDR.94,877,540/ ha and IDR 113,998,539/ ha. The labor productivity obtained by each farmer is IDR $277,779 /$ HKO and IDR 443,882/ HKO and the value of capital productivity obtained was $194.1 \%$ for independent farmers and $192.40 \%$ for group farmers.

\subsection{Suggestion}

Based on the results of the research obtained, both 
independent and group red chili farming provides considerable benefits for farmers. However, if based on the results of data calculations in the field, group farmers have more income and profits than independent farmers, so it would be better if independent farmers could join group farmers. In addition to having considerable advantages, group farmers receive assistance from the government in the form of production and financial means that can help reduce farmer expenses and access to a fairly extensive market network is one of the advantages of joining a farmer group.

In addition, farmers in Sukamantri District need to pay attention to important things in red chili farming such as in the process of seeding, fertilizing and maintaining the chili plants produced can be maximally and of high quality.

\section{REFERENCES}

[1] Anggraeni, Ervina Ika Nur. (2018). Feasibility of Red Chili Farming In the Merapi Eruption Area, Wukirsari Village, Cangkringan District, Sleman Regency.

[2] Domestic Trade Assessment Center, Trade Research and Development Agency. 2019. Analysis of the Development of Staple Food Prices in Domestic and International Markets. RI Ministry of Trade. Retrieved November

18 , 2020.http://bppp.kemendag.go.id/media_content/2019/ 04/BAPOK_BULAN_FEBRUARI_2019.pdf

[3] Central Bureau of Statistics of Ciamis Regency. (2019). Ciamis Regency in Figures 2019. Central Bureau of Statistics.

https://ciamiskab.bps.go.id/publication/2019/08/16/92 2d62137ff39b0136487ee4/kabupaten-ciamis-dalamangka-2019.html

[4] Evaliza, D., Ekasari Putri, N., \& Fauza, H. (2015). Lotanbar Chili Farming Analysis In Support Of a New Superior Cultivar rrom The District of Fifty Cities. International Journal on Advanced Science, Engineering and Information Technology, 5 (1), 40-43.

[5] Fajar, Muhammad. (2018). Review of Big Chili and Cayenne Pepper Production Data. https://www.researchgate.net/publication/324133429 TELAAH_DATA_PRODUKSI_CABAI_BESAR_DA N_CABAI_RAWIT/citation/download. Accessed on 14 July 2020

[6] Pratama, MR (2019). Feasibility Analysis of Red Chili Farming (Lubuk Cuik Village, Lima Puluh District, Batu Bara Regency, North Sumatra) (Doctoral Dissertation, Faculty of Agriculture, Islamic University of North Sumatra).

[7] Purba, USA (2019). Analysis of Inorganic and Semi Organic Red Chili Farming Income in South Lampung Regency.

[8] Rudi, Muhammad. (2016). Feasibility of Red Chili Farming on Sand in Karangsewu Village, Galur District, Kulon Progo Regency.

[9] Santika, Adhi. (1996). Agribisnis Cabai. Jakarta: Penebar Swadaya
[10] Soekartawi. (1995). Analisis Usahatani. Jakarta: Universitas Indonesia (Ui-Press)

[11] Sugiyono. (2018). Metode Penelitian Kuantitatif Kualitatif dan $R \& D$. Bandung : Alfabeta

[12] Wahidmurni, W. (2017). Pemaparan Metode Penelitian Kualitatif.

[13] Waldi, W. (2017). Analysis of the Feasibility of Red Chili Farming in the Pantai Pasir, Panjatan District, Kulon Progo Regency. Agritas Scientific Journal, 1 (1).

[14] West Java Bappeda Public Relations. (2016). Bandung. http://bappeda.jabarprov.go.id/mentan-canangkanmovement-tanam-cabai/. Accessed on July 14, 2020

[15] Zamrodah, Y., \& Pintakami, LB (2020). Income and feasibility of cayenne pepper farming. JASE: Journal of Agricultural Socio-Economics, 1 (1), 41-46. 